\title{
La poesía temprana de Carlos Pellicer: del cosmopolitismo exotista a la historicidad poética
}

\author{
Jason Lee Pettigrew \\ Middle Tennessee State University \\ Jason.Pettigrew@mtsu.edu
}

\begin{abstract}
Resumen: La poesía temprana de Carlos Pellicer ejemplifica un cambio fundamental en la lírica hispanoamericana. Su obra revela la transición entre el cosmopolitismo ahistórico y exotista y una nueva poesía de conciencia histórica que retoma la historia y la realidad propias de Hispanoamérica. Específicamente, "La elegía de tus ojos" (1914), "Imperial agonía" (1916) y "Oda a Cuauhtémoc" (1924) ejemplifican este nuevo enfoque durante el período cosmopolita de la poesía hispanoamericana. Al comparar el acercamiento exotista a la historia autóctona en los dos poemas juveniles con el tratamiento comprometido que aboga por la resistencia continental ante la colonialidad en "Oda a Cuauhtémoc", ilustraré este cambio representativo en la obra temprana de Pellicer.
\end{abstract}

Aвstract: The early poetry of Carlos Pellicer exemplifies a fundamental change in Hispanic American poetry. His work reveals the transition between exotic, ahistorical cosmopolitism and a new poetry of historical consciousness that explores Hispanic America's own history and reality. Specifically, "La elegía de tus ojos" (1914), "Imperial agonía" (1916) and "Oda a Cuauhtémoc" (1924) exemplify this new focus during the cosmopolitan period of Hispanic American poetry. Upon comparing the exotic approach to indigenous history in the two earlier poems with the socially compromised treatment that advocates continental resistance to coloniality in "Oda a Cuauhtémoc", I will illustrate this representative change in the early work of Pellicer.

Palabras Clave: Carlos Pellicer, cosmopolitismo, historia precolombina, Cuauhtémoc.

Keywords: Carlos Pellicer, cosmopolitism, pre-Columbian history, Cuauhtémoc.

La poesía temprana de Carlos Pellicer (1899-1977) ejemplifica un cambio fundamental en la lírica hispanoamericana. Su obra revela la transición entre el cosmopolitismo ahistórico y exotista y una nueva poesía de conciencia histórica que no solo retoma la historia y la realidad propias de Hispanoamérica sino que también reintegra el espacio simbólico precolombino que fue derrumbado y fragmentado por la Conquista. 
En el presente estudio analizo la poesía temprana del poeta mexicano, enfocándome en tres textos que poetizan la historia precolombina y la Conquista española. Específicamente, consideraré "La elegía de tus ojos" (1914), "Imperial agonía" (1916) y "Oda a Cuauhtémoc" de Piedra de sacrificios (1924) como ejemplos de un nuevo enfoque en la historia y la cultura propias durante el período cosmopolita de la poesía hispanoamericana. ${ }^{1}$ Mucha de la poesía de la época cosmopolita tiene como un rasgo principal la ahistoricidad. Es decir, muchos de los poetas, especialmente los modernistas, rehúyen la historia y las tradiciones culturales propias del continente para hablar de París, de la mitología greco-romana, o de Asia, por ejemplo. En el prefacio de Poesía en movimiento (1966), Octavio Paz señala este cambio en la trayectoria de la lírica hispanoamericana: "Nuestra tradición es también y sobre todo un estilo polémico, en lucha constante con la tradición española y consigo mismo: al casticismo español opone un cosmopolitismo; a su propio cosmopolitismo, una voluntad de ser americano" (4). Con respecto a la obra de Pellicer y de algunos de sus contemporáneos, Óscar Rivera-Rodas también ha afirmado que "[s]imultáneamente al cosmopolitismo enajenado, surgieron escritores y poetas que empezaron a recuperar la realidad americana en sus obras. Así podemos señalar la tarea precursora de Carlos Pellicer" (2011:328-329). Entonces, afirmo que los textos poéticos antes aludidos constituyen un discurso de transición entre ese cosmopolitismo ahistórico y exotista y una nueva conciencia de la historia hispanoamericana que surgirá en la lírica posterior. Al comparar el acercamiento exotista a la historia autóctona en "La elegía de tus ojos" e "Imperial agonía" con el tratamiento comprometido que aboga por la resistencia solidaria ante la colonialidad en "Oda a Cuauhtémoc", ilustraré este cambio representativo en la obra temprana de Pellicer.

En los dos poemas juveniles de 1914 y 1916 podemos observar la renuncia de la ahistoricidad, aunque el autor todavía se aferra a la estética modernista, y los inicios de una nueva conciencia histórica que llegará a fruición en la poesía de la década de 1950 y 1960. De hecho, "Impe-

${ }^{1}$ El acercamiento crítico de este trabajo proviene de la periodización propia de la literatura hispanoamericana, propuesta por primera vez por José Carlos Mariátegui, que la divide en tres grandes etapas: la colonial, la cosmopolita y la nacional. Según esta periodización, la época cosmopolita incluye el modernismo (1880-1905), el posmodernismo (1905-1920), el vanguardismo (1920-1935) y el postvanguardismo (1935-1950). 
rial agonía" parodia el poema modernista de Julián del Casal titulado "La agonía de Petronio" (1892). Empleando los rasgos estilísticos del preciosismo modernista, Pellicer altera la temática cosmopolita y vuelve su mirada hacia la época precolombina de su patria. Para 1924, ya habiéndose iniciado el vanguardismo, en "Oda a Cuauhtémoc" Pellicer se apropia de la historia del guerrero mexica para hacer un llamado a la unidad continental y a la resistencia solidaria ante las imposiciones foráneas y el legado de la colonialidad. Basándome en su representación de la resistencia de Cuauhtémoc durante la Conquista española, demostraré que Pellicer eleva su poetización de la historia del guerrero a un nivel mítico al incorporar al subtexto el mito de Quetzalcóatl y el mito mixteca de la fundación de Tilantongo, en la actual Oaxaca.

Como bien dijo Edward J. Mullen, Carlos Pellicer es "uno de los vates más elogiados de la América Latina cuya enorme y variada obra va recibiendo cada día más atención" (51). Por su parte, en un ensayo sobre la obra de Pellicer escrito en 1955 e incluido en Las peras del olmo, Octavio Paz también señaló la importancia de este poeta en la trayectoria de la lírica mexicana: "Ramón López Velarde y José Juan Tablada son los iniciadores de la poesía moderna en México. [...] Nuestro primer poeta realmente 'moderno' es Carlos Pellicer" (75). Paz nota un cambio en la trayectoria de Pellicer, observando que su obra "pretende ordenar al mundo. En los primeros tiempos este orden era el del juego; después fue un orden monumental, como si quisiera recordar a los toltecas y a los mayas" (82). Esta observación de Paz no solo subraya un cambio en la obra de Pellicer sino que también sugiere un cambio de suma importancia en la lírica hispanoamericana. Se trata del abandono de la ahistoricidad característica de la obra de muchos poetas modernistas y vanguardistas, para dar paso a la historicidad poética, es decir, la poesía que explora profundamente la historia y la cultura propiamente hispanoamericanas.

\section{“La elegía de tus ojos” (1914)}

Uno de los poemas más tempranos de Pellicer, "La elegía de tus ojos", ya demuestra un sentido nuevo de historicidad. Escrito en 1914, en el apogeo del posmodernismo y durante la Revolución mexicana, cuan- 
do el poeta tenía apenas unos quince años, ${ }^{2}$ este poema se adhiere a la estética del preciosismo modernista. Emplea un tono de elegancia refinada para describir los ojos de la amada que el poeta observa en un jardín, características típicas del Modernismo. El poeta es encantado por el reflejo de la mujer en las aguas de una fuente. A nivel temático, el poema demuestra un acercamiento a la historia propia con múltiples referencias al pasado azteca y a la Conquista, pero no deja de sugerir cierto exotismo. Por su parte, Francisco Pabón señala que en Colores en el mar, el poemario que Pellicer publicó poco después en 1921, "la valoración del motivo indígena no deja de obedecer a una estética que en el fondo busca lo exótico [...y es] una extensión del preciosismo modernista" (54-55).

Aunque Pellicer inicia y da fin a "La elegía de tus ojos" con una serie de imágenes habituales para el Modernismo, aquel universo cosmopolita usual no brota de su percepción de los ojos de la amada. En cambio, afloran paisajes e historia de la comarca propia. Los ojos de la amada reflejan un paisaje autóctono, como un espejo que revela el pasado prehispánico, y en el cual el poeta observa y admira la elaboración artística de la piedra nativa:

Tus ojos son las quejas de un alma que no existe, son dos espejos mágicos, son almas del paisaje de la barbarie azteca que es bella y es muy triste y entre la piedra embute su escultural encaje.

Mientras que otros poetas se inspiraban en la Grecia o la Roma antiguas, en las ciudades cosmopolitas europeas, o en el Oriente, Pellicer centraba su mirada en un paisaje mexicano con los vestigios de sus civilizaciones originarias. Octavio Paz, respecto a este enfoque cosmopolita del modernismo, en "Literatura de fundación" en su colección de ensayos Puertas al campo, señala que

\footnotetext{
${ }^{2}$ Existe confusión sobre la fecha del nacimiento del poeta. Mientras que 1899 generalmente se acepta como el año en que nació, no se sabe con exactitud y hasta se ha pensado que Pellicer nació en 1897 (De la Selva: 59). De ser correcto este último año, Pellicer hubiera tenido 17 años al escribir "La elegía de tus ojos".
} 
[a] fines del siglo xIx la literatura hispanoamericana cesa de ser un reflejo de la espańola. Los poetas "modernistas" rompen bruscamente con el modelo peninsular. Pero no vuelven los ojos hacia su tierra sino hacia París. Van en busca del presente. Los primeros escritores hispanoamericanos que tuvieron conciencia de sí mismos y de su singularidad histórica fueron una generación de desterrados (18; cursivas mías).

Los siguientes versos, repetidos al final del poema, nos hacen pensar en aquellos cosmopolitas desterrados que cederán el paso a los poetas que vuelven su mirada de tierras y tradiciones ajenas para encantarse, como el joven Pellicer, con la historia y la realidad propias. Los ojos de la amada se describen como el faro que guiará al cosmopolita desterrado, o náufrago, desde el Oriente a la comarca propia: “Ojos que son los faros de un océano de vida / que aguardan a algún náufrago que vendrá del Oriente / a fundirse en la gloria de sus lampos de vida..." (vv. 2-4).

Está claro que el poeta joven ha estudiado, y valora, la historia y el arte de la época precolombina. Este universo prehispánico idealizado se encierra en los ojos de su amada, entrando así en estrecha relación con la belleza que percibe y admira en ella. Este acercamiento a la temática precolombina como a una amada, claramente una exterioridad exótica y encantadora, por otra parte no deja de sugerir un conflicto interior en el poeta. Cabe subrayar que el enunciador insiste que los ojos de la amada son "espejos mágicos", sugiriendo así que observa el legado azteca no solo dentro de ella sino también dentro de sí mismo (v. 10). El canto del poeta se inspira en la memoria histórica colectiva de una civilización ancestral que sobrevive como una parte enigmática de su identidad:

$$
\begin{aligned}
& \text { Y así, entre los lampos de tus ojos divinos } \\
& \text { pasa el recuerdo cálido de mi raza de gloria } \\
& \text { que vive hoy en tus ojos su enigma vespertino } \\
& \text { y canta en mi memoria. }
\end{aligned}
$$

Los ojos de la amada sirven solo como un pretexto, un vaso que el poeta llena con sus percepciones imaginativas de las cortes aztecas y de escenas de la Conquista. Así, la celebración de la belleza de la amada se convierte en una elegía que expresa una gran tristeza sobre la pérdida de ese mundo bello: 
Tus ojos son la queja de la perdida raza; quizás serán los versos de Nezahualcóyotl; a su luz pasan héroes, doña Marina pasa, pasan los sacerdotes de la Luna y del Sol.

Y pasan las visiones de los paisajes viejos: Tenochtitlán la diosa del valle, sus canales empolvados de luna, de nerviosos reflejos que dibujan las quillas en sus regios cristales.

El poema constituye un lamento elegíaco por la pérdida de la civilización autóctona, fragmentada por la Conquista y la Colonia:

Quetzalcóatl que predice la caída del Sol azteca y del águila altiva y vencedora que rodará en su nido de civilización cuando alcen los cañones su voz atronadora. ¡Y las postreras horas de esa paz mexicana!

(vv. 27-31)

Para representar esa pérdida profunda, Pellicer se apropia del símbolo precolombino de las plumas del quetzal, una imagen constante en el arte, en los atavíos y en la literatura náhuatl. Ángel María Garibay K. destaca esta imagen en Historia de la literatura nábuatl:

[1]a piedra preciosa y el oro, juntamente con las bellas plumas de aves policromadas, son para la imaginación náhuatl el más alto ápice de la hermosura. Las hallamos en muchos cantos como término de comparación. ¿No es hermoso símil, varias veces repetido, de la fugacidad de la vida el perecer de estos objetos valiosos y bellos? (103).

Pellicer reintegra a la lírica moderna este motivo común de la lírica náhuatl: las plumas del quetzal como símbolo de la belleza y de la fugacidad de la vida, también sugiriendo la fugacidad del dominio de las civilizaciones oriundas:

El quetzal, el quetzal,

el pájaro que luce su mágico plumaje. 
El quetzal, que al desdoblar sus alas se lleva otro paisaje...

Ya llega don Hernando, la escena ya se pierde entre el clamor inmenso de los conquistadores. El quetzal ya no vuelve, y en su plumaje verde hacen eco los ecos de todos los dolores.

(vv. 35-42)

Ya habiendo mencionado al poeta precolombino Nezahualcóyotl, Pellicer sin duda había leído su obra. En un poema atribuido a Nezahualcóyotl, el bardo de Texcoco canta la fugacidad de la vida de los reyes (el mismo tema que trata Pellicer). Nezahualcóyotl emplea el motivo de las plumas del quetzal de la siguiente manera:

Aunque sea jade: también se quiebra, aunque sea oro, también se hiende, y aun el plumaje de quetzal se desgarra: ¡No por siempre en la tierra: Sólo breve tiempo aquí!

(Garibay 1965, 2: 3-4)

Así señalamos un posible diálogo intertextual entre el texto de Pellicer y la obra de Nezahualcóyotl. Queda claro que el joven Pellicer, en lugar de inspirarse en la obra de los poetas franceses contemporáneos, como muchos modernistas, también se inspira en la tradición lírica oriunda.

Por otro lado, cabe subrayar que esta "elegía" de Pellicer se asemeja al género precolombino del icnocuicatl, los "Canto[s] de desolación, de orfandad" (Garibay 1992: 89). Según Garibay, estos cantos precolombinos "tienen parentesco con las elegías [...] de los poetas de Occidente, en que se canta la amargura del vivir" (89). Como la poesía modernista, los icnocuicatl "tienen un aire de elegancia y fervor de refinamiento" (89). Ese aire elegante y refinado del icnocuicatl se combina en el texto de Pellicer con símbolos y motivos literarios de la poesía náhuatl, y con referencias históricas al imperio mexica, para lamentar su pérdida. Aquí vemos los inicios de la reincorporación de motivos poéticos precolombinos que Pellicer profundizará en Piedra de sacri- 
ficios y en su obra posterior. Así, "La elegía de tus ojos" constituye un ejemplo muy temprano del acercamiento a la poesía que busca recobrar la lírica oriunda y un sentido de historicidad propia. Al final del poema, el enunciador no solo lamenta dejar a su amada llorando en el jardín idealizado que abandona, sino también lamenta no poder acceder a ese pasado precolombino relegado a los pliegues de la historia.

\section{“IMPERIAL AGONíA” (1916)}

Otro poema juvenil nunca coleccionado por Pellicer, "Imperial agonía" (1916), también revela un intento por recobrar un sentido de historicidad propia en la lírica mexicana. Como "La elegía de tus ojos", se adhiere a la estética modernista y representa con exotismo la historia de la rivalidad entre el tlatoani Tezozómoc del altepetl de Azcapotzalco (?-1427) y el joven Nezahualcóyotl (1402-1472), el poeta y tlatoani de Texcoco. Como narra José Ignacio Dávila Garibi (1888-1981) en Episodios de la vida de Netzahualcóyotl (1911), Tezozómoc manda matar al padre de Nezahualcóyotl, Ixtlixóchitl el tlatoani de Texcoco, cuando su hijo es muy joven para apoderarse de su reino. Antes de morir, Ixtlixóchitl le pide a su hijo que se vengue de Tezozómoc, y el príncipe joven pasa largos ańos planeando recuperar el reino de su padre. Poco antes de su muerte, Tezozómoc tiene una pesadilla extraña en que Nezahualcóyotl, convertido en un águila, entra al palacio de Azcapotzalco, ataca a Tezozómoc, le arranca el corazón con el pico y lo devora. Los adivinos de Tezozómoc interpretan el sueńo como un presagio de la venganza de Nezahualcóyotl para recobrar el reino de su padre. Tezozómoc, temiendo las predicciones, manda a sus hijos que maten a Nezahualcóyotl cuando venga a su funeral para evitar que su familia pierda el trono de Azcapotzalco y el reino de Texcoco. La conspiración fracasa y Nezahualcóyotl eventualmente recobra su reino en 1427 (932). Pellicer poetiza la pesadilla y la muerte de Tezozómoc, relatando parte de esta historia famosa del Anáhuac precolombino que circulaba entre el pueblo y, según Garibay, "debió ser deleite de jóvenes, niños y viejos" (1992: 491). ${ }^{3}$

\footnotetext{
${ }^{3}$ Episodios de la vida de Netzahualcóyotl (1911) de José Ignacio Dávila Garibi posiblemente constituye el hipotexto en que Pellicer basa "Agonía imperial", ya que existen
} 
Por otra parte, "Imperial agonía" constituye una parodia de "La agonía de Petronio", uno de los textos de Nieve (1892) del poeta cubano Julián del Casal (1863-1893). ${ }^{4}$ El poema de Casal ejemplifica el modernismo cosmopolita y ahistórico, con respecto a la tradición histórica propiamente hispanoamericana. Casal se enfoca en la historia del Imperio Romano, relatando en sus versos refinados imágenes parnasianas del suicidio de Petronio, el escritor y político romano de la corte de Nerón que fue acusado de participar en una conjuración fracasada para matar al emperador. Pellicer, usando el mismo estilo refinado y parnasiano de Julián del Casal, no se enfoca en el Imperio Romano sino en el Anáhuac antiguo, relatando la muerte de Tezozómoc antes de la conjuración planeada por Nezahualcóyotl para recobrar el reino perdido por su padre. Hay varias semejanzas entre los textos que nos hacen considerar "Imperial agonía" una parodia de "La agonía de Petronio". Tanto en el poema de Casal como en el de Pellicer, las figuras históricas mueren dentro de un palacio suntuoso, un espacio interior elegante, rodeados de cortesanos y ayudantes. En el poema de Casal, el enunciador impasible describe con imágenes luminosas y sensoriales la muerte de Petronio, a quien llama el "bardo decadente" (v. 4). Por su parte, Pellicer empieza y termina su poema con descripciones elegantes de la

semejanzas con el estilo imaginativo y literario de aquel texto, publicado en México por primera vez en 1911 y republicado en 1913, poco antes de que Pellicer escribiera su poema. Otras fuentes hipotextuales posibles son El emperador Nezahualcóyotl considerado como poeta elegíaco (1878) de Pedro Mascaró y Sosa (1857-1904) y dos textos indígenas: los Anales de Cuauhtitlan en el Códice Chimalpopoca o la Historia chichimeca de Fernando de Alva Ixtlilxóchitl (1568?-1648).

${ }^{4}$ Pellicer sin duda conocía el tema del poema de Casal. Poco antes de componer "Imperial agonía" en 1916, el cubano escribió "La muerte de Petronio", una serie de cinco sonetos fechada entre 1914 y 1915 . Este texto precursor revela una estética muy influida por el Modernismo en versos como los siguientes, del último soneto:

Ondulantes los cuellos de los cisnes flotantes, ondulantes los muslos de las ninfas de rosa, en los cisnes las ninfas y los cisnes galantes ondulando el espejo de las aguas. Curiosa y anhelante la risa del estanque de plata copia en círculos ágiles la pagana visión: luz, vestales, palomas, música áurea. Y recata su figura felina bajo el palio, Nerón. 
naturaleza que rodea al palacio, pero al igual centra su percepción en las imágenes sensoriales del palacio donde muere Tezozómoc, a quien llama "fiera decadente" (v. 13), una transformación de la frase "bardo decadente" empleada por Casal. También hay paralelos en las acciones que realizan los cortesanos en los dos poemas. En el texto de Casal los cortesanos atienden a Petronio, trayéndole el vino que el moribundo demanda (vv. 22-24). Igualmente, en el poema de Pellicer, los cortesanos de Tezozómoc le abanican y le traen "yerbajos / que un hombre de la selva a gran súplica trajo" (vv. 28-29). Otra semejanza son los títulos; no obstante "La agonía de Petronio" sugiere el sufrimiento de un solo hombre. En cambio, "Imperial agonía" también sugiere el sentimiento del poeta ante un pasado precolombino perdido. Así, afirmo que el texto de Pellicer parodia el poema de Casal, criticando el cosmopolitismo reinante y abogando por una poesía enfocada en la historia y en las tradiciones propias.

Pellicer poetiza el sueño y la rivalidad entre Tezozómoc y Nezahualcóyotl, limitándose, como Casal, a describir la escena de su agonía y muerte. Primero, describe el miedo del usurpador y su arrepentimiento por apoderarse del reino de Texcoco injustamente:

...llora y retiembla y se angustia y lo amaga

un recuerdo terrible: la perspectiva aciaga

de una infamia tan cruel y tan negra, tan negra,

que ella sola es el símbolo que la maldad integra!

(vv. 16-19)

El escritor también nos presenta el temor de Tezozómoc ante la venganza de Nezahualcóyotl presagiada en su sueño: “¡Se vengará!, se dice. ¡Se vengará!... ¡Quién sabe / a qué plan de venganza dará vida esa ave / cuyo vuelo me obstina, oh Netzahualcóyotl!" (vv. 20-22). En el momento de la muerte de Tezozómoc, Pellicer da fin al poema con una descripción elegante del paisaje mexicano, valorizando así tanto la historia como el paisaje propios:

\section{...La agonía va hilando}

la tela de sus fúnebres abetos, rezongando

Tezozómoc se muere ... En la noche la luna

y de otońo, el tiempo le esconde una a una 
las horas... Vense lejos,

las pirámides álgidas de los volcanes viejos.

(vv. 30-35)

Aunque se tata de un acercamiento todavía exotista a la historia precolombina, queda claro que tanto "La elegía de tus ojos" como "Agonía imperial” demuestran que, aun en sus textos más tempranos, la obra de Pellicer representa un cambio temático en la lírica hispanoamericana. El cosmopolitismo ahistórico y la exploración de tradiciones ajenas dan paso a la historicidad y a la celebración reivindicatoria de la historia oriunda tras la destrucción cultural que inició la Conquista siglos antes.

“Oda a Cuauhtémoc” de Piedra de SACRIFICIOS (1924)

En 1924, Pellicer publica Piedra de sacrificios: Poema iberoamericano, libro que, antes del Canto general de Neruda, celebra a toda la América Latina, cantando su geografía, sus pueblos, su historia, sus héroes nacionales, y llamando a la unión continental. En adelante, analizaré "Oda a Cuauhtémoc", uno de los textos más representativos del acercamiento profundo y comprometido, ya no exotista, a la historia autóctona en la obra del vate. Existe una larga historia en el uso del icono de Cuauhtémoc para fines sociales y políticos, con tensiones y contradicciones internas, particularmente desde la época de Benito Juárez y durante el Porfiriato, cuando se construyeron monumentos dedicados al guerrero, con el fin de unir la nación. Después de la Revolución mexicana, y particularmente durante la década de los 1940, Cuauhtémoc se convirtió en símbolo de las revoluciones sociales y sirvió como material para escritores como Pellicer y para pintores y muralistas como Diego Rivera y David Alfaro Siqueiros. ${ }^{5}$

\footnotetext{
${ }^{5}$ Dos artículos complementarios de Christopher Fulton, "Cuauhtémoc Awakened" y "Cuauhtémoc Regained" examinan las representaciones artísticas de Cuauhtémoc en el siglo xIX y el siglo Xx, analizando el proceso por el cual se convirtió en símbolo nacional. Fulton delinea las representaciones artísticas de Cuauhtémoc, sobre todo en las artes plásticas. Analiza con detalle el uso del símbolo por el gobierno autocrático de Porfirio Díaz en la construcción del monumento a Cuauhtémoc en el Paseo de la Reforma. El monumento "was created as a symbol of Mexico's triumph over foreign intervention and of the national unity achieved by the liberal regime under its new
} 
Igualmente, el mundo poético de Pellicer se inspira muchas veces en el referente precolombino. Francisco Pabón señala que en Piedra de sacrificios, utiliza "un nuevo lenguaje poético que se inspira en símbolos, mitos y supervivencias del México antiguo. La valoración del mundo indígena en esta obra consiste en la elaboración de toda una topografía poética cuyas coordenadas se dan en los órdenes lingüístico, histórico, arqueológico y simbólico mitológico" (207). Por su parte, Raúl Leiva pone de relieve la identificación personal entre Pellicer y el guerrero mexica: "[e]l poeta reconoce en sí mismo, en lo hondo, al salvaje azteca, manejador de dardos que lanza [...] hacia la inmensidad. Es un flechador de estrellas, Cuauhtémoc poético, embebido en dar en el blanco de lo inesperado" (94). Pellicer ya no alude a la tradición greco-romana al retratar a Cuauhtémoc, como lo hizo en el la tercera parte de "Tríptico azteca" (1914), dedicada al guerrero: "A veces me figuro que eres griego o romano / y eres las dos cosas; cual si una roja mano / las fundiese en la lumbre del azteca volcán" (vv. 1-3). En cambio, eleva la historia de la resistencia de Cuauhtémoc durante la conquista española a un nivel mítico al transformar e incorporar al relato dos mitos del orden simbólico mitológico precolombino: el mito de la muerte y la transfiguración de Quetzalcóatl, y el mito mixteca de la fundación de Tilantongo en la actual Oaxaca. Pellicer presiente la repetición de la historia y la amenaza de una invasión similar a la española por parte de los Estados Unidos. Además, un análisis cuidadoso del poema revela ecos de los cuauhcuicatl, los "cantos de águila" de la poesía náhuatl, que elogiaban a un líder fallecido en la guerra.

En cuanto al conflicto mismo, Pellicer alaba la voluntad y la resistencia de Cuauhtémoc mientras desvaloriza los actores históricos

head of state" (2008a: 21). Durante esta época, el símbolo de Cuauhtémoc "reflected a vision of history which connected the modern state with the pre-Hispanic empire, and the puissant monarch was eagerly adopted as a symbol of the independent nation ruled by a centralized political authority" (47). Sin embargo, bajo el Porfiriato, "the symbol faltered before the cuestión indigena. Cuauhtémoc was depicted as an exceptional native leader and model for modern-day heads of state [...] but he did not represent the aspirations of the indigenous people as such, or of the ever-growing mestizo population" (47). Con respecto al uso del icono en el siglo xx, Fulton analiza las tensiones "between the government's use of the figure to sustain a nationalist ideology and the adoption of the symbol by dissidents and champions of subordinated groups [...] The symbol is caught in a dialectic of 'top down' and 'bottom up' cultural processes, through which it is continually reinterpreted and transformed" (2008b: 43). 
europeos. Las figuras europeas de la Conquista, elevadas a un nivel icónico por la historiografía tradicional, apenas merecen mención. La llegada de los europeos, considerada en las crónicas castellanas el advenimiento de la luz de la civilización al llamado "nuevo mundo", se retrata como una embestida maligna y destructora. Pellicer invierte la dicotomía anticuada que trata la Conquista en términos de una lucha entre la civilización europea y la barbarie indígena. En cambio, lamenta la destrucción cultural de la invasión europea y el legado de la colonialidad. Los conquistadores se retratan como actores anónimos y brutales mientras que las civilizaciones precolombinas representan su contrapunto:

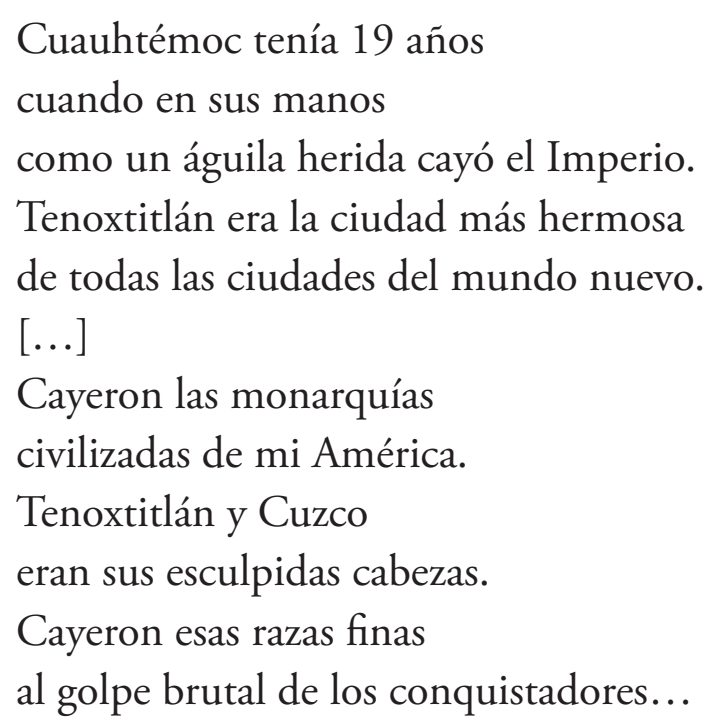

(vv. 36-40, 64-69)

Describe la colonización de América en términos de violencia, explotación y maltrato, una imposición que el poeta todavía siente en su presente, el legado de la colonialidad:

¡Desde hace cuatrocientos años

somos esclavos y servidores!

¿Quién puede mirar el cielo con dulzura

cuando del oprobio de los europeos

nacieron estos pueblos de mi América,

débiles, incultos y enfermos?

Marcaron a los hombres como si fueran bestias

y en el rostro del campo y en el hígado de la mina 
vivieron la crueldad, la miseria y el tedio.

$Y$ ahora mismo todavía

lo miro, lo palpo y lo siento.

(vv. 76-86; cursivas mías)

El poeta rechaza la perspectiva de las crónicas y la historiografía tradicional que retratan a los líderes indígenas como bárbaros que resistían la civilización europea, lo cual se iba a establecer por voluntad del dios "único y verdadero". Según afirma Francisco Pabón, Pellicer presenta a Cuauhtémoc en un "sentido mítico" (76), celebrando su vida y su voluntad con "un himno ritual, en el cual Cuauhtémoc es divinizado" (75). A lo largo del poema, Pellicer conecta la historia de Cuauhtémoc con mitos y leyendas precolombinos, elevando así al guerrero mexica del orden histórico al orden simbólico mitológico.

A lo largo del texto, Pellicer alude al mito de Quetzalcóatl en relación a la invasión europea y la resistencia de Cuauhtémoc. Según la leyenda, Quetzalcóatl viajó a la orilla del mar y, tras prenderse fuego, su corazón subió a los cielos y se transformó en la estrella de la aurora. Algunas fuentes de la leyenda hablan del regreso futuro de Quetzalcóatl para recobrar su reino en la tierra. Asimismo, la historiografía tradicional nos expone que Moctezuma confundió la llegada de los españoles con el regreso de Quetzalcóatl y, por eso, sentía que la pérdida de su reino era inevitable. Así Pellicer trata el motivo en el poema:

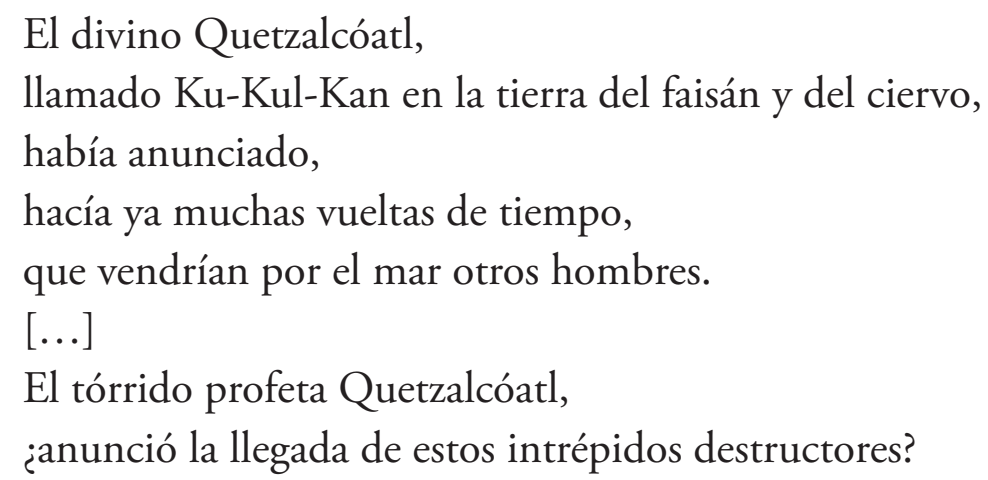
(vv. 41-45, 72-73)

La estrella de Quetzalcóatl domina el poema como una presencia abrumadora y maligna que causa pavor y duda ante un destino adverso, en lugar de esperanza para el regreso futuro de Quetzalcóatl, por su asociación con la Conquista y la colonización. Así, el mito cobra un 
nuevo significado en el presente de la enunciación: "Y desde entonces una estrella tristísima / se alarga sobre las llanuras y se ahonda junto a los montes" (vv. 74-75). Angustiado por la estrella de Quetzalcóatl, el poeta expresa un sentido de fatalidad ante un destino adverso que parece estar escrito en las estrellas: "Pues ¿quién puede volver a mirar serenamente las estrellas, / cuando todo semeja que el destino / va a aplastarnos con sus plantas de piedra?" (vv. 61-63). Como ha señalado Eugene Moretta, el tema del destino en Piedra de sacrificios "se entiende en primer lugar como fatalidad que frustra los proyectos humanos" (91), y los versos del poeta "[i]dentifican en la historia iberoamericana un sombrío determinismo que se funda en la larga serie de depredaciones sufridas por el pueblo, llegando hasta el imperialismo cada vez más amenazante de los Estados Unidos" (92). Su impresión de fatalidad, o como la llama en el texto, el "destino de la tragedia inexorable y gigantesca" (v. 93) o su "duelo grandioso como una ola de basalto" (v. 54), pesa sobre el escritor y parece que solo le queda la incertidumbre y el anhelo de tiempos mejores. Interroga, “¿Nadie podrá devolverme nunca / las dulces horas del amor y la alegría de cantar en el campo?” (vv. 55-56).

Por otro lado, la resistencia de Cuauhtémoc se presenta como contrapunto del destino fatal que el poeta asocia con el lucero de Quetzalcóatl. Pellicer prefiere celebrar la vida y la voluntad del guerrero, que tiene su propia estrella en su mundo poético:

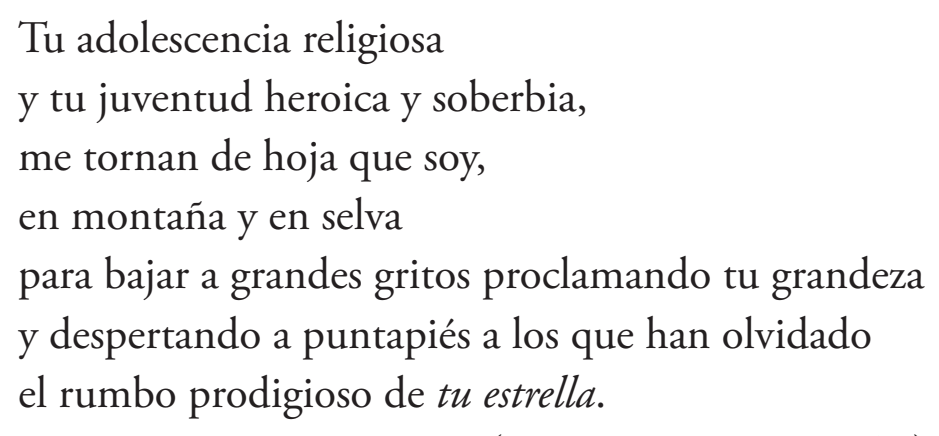

(vv. 15-21; cursivas mías)

El heroísmo y la voluntad de Cuauhtémoc crecen en el poeta que, si primero sentía la soledad y la fragilidad de una hoja que solo cae después, inspirado por el guerrero, siente el poder y la grandeza de una montańa o de una selva. Así, el poeta vence ese sentimiento de fatalidad asociado con el lucero de Quetzalcóatl, infundiéndose con la voluntad 
de Cuauhtémoc. Pellicer desea que el pueblo se olvide de la estrella "tristísima" de Quetzalcóatl, y todas esas "estrellas caudales que iluminan el miedo" (v. 31) para establecer, simbólicamente, una estrella para Cuauhtémoc que inspire la resistencia unida: "Consagremos al primero de los mexicanos / una montańa o un pedazo de cielo. / Alegrémonos por la maravilla de sus actos" (vv. 24-26; cursivas mías). En lugar del regreso de Quetzalcóatl, Pellicer sugiere la posibilidad del regreso del espíritu de resistencia del guerrero mexica.

Antes de seguir, es necesario señalar que la leyenda mixteca de Tilantongo explica la creación de los seres humanos y la fundación de Tilantongo durante el Preclásico Medio en el actual estado de Oaxaca. Definitivamente, Pellicer conocía la leyenda de Tilantongo ya que elaboró su propia versión poetizada, "Romance de Tilantongo" en $1937 .{ }^{6}$ La leyenda relata cómo uno de los hijos de los árboles de Achiutla, uno de los primeros caciques, salió a conquistar alguna tierra donde su gente pudiera establecerse. Cuando llegó a la región que después sería Tilantongo encontró una tierra deshabitada donde solo reinaba el sol. El cacique supuso que el sol era el señor de esa región y, ya que sentía que le impedía apoderarse de la tierra con sus rayos ardientes, lo retó a la batalla. El cacique le lanzó flechas mientras que el sol proyectaba sus rayos de fuego. Cuando por la tarde el sol se escondió detrás de una montaña y tiñó las nubes de rosado, el joven creyó que había matado al sol de un flechazo. Se declaró el vencedor y, posteriormente, fundó la capital de su reino (Westheim: 65; Gay: 22-23). En Historia de Oaxaca (1881), José Antonio Gay cita la Geográfica descripción de Oaxaca de 1674 del Padre Francisco Burgoa, recordándonos que "la victoria del sol es tan general en el blasón de los mixtecas, que en los escudos de sus armas pintaban un capitán armado, con su penacho de plumas, arco, rodela y saetas en sus manos, y en su presencia el sol ocultándose entre nubes pardas" (22).

\footnotetext{
6 "Romance de Tilantongo", coleccionado en Recinto y otras imágenes (1941), constituye una reconstrucción poética del mito de creación mixteca que Pellicer consultó en la Geográfica descripción de Francisco de Burgoa (1674) o la versión recopilada en la Historia de Oaxaca del padre José Antonio Gay (1881). En una entrevista, el mismo poeta parece haber confundido las fuentes, ya que señaló que sacó la idea de "la Historia de Oaxaca del Padre Burgoa" (Pabón: 231).
} 
Pellicer alude a esta leyenda varias veces en "Oda a Cuauhtémoc", con imágenes que sugieren la batalla con un astro, la estrella de la aurora de Quetzalcóatl, que en el poema representa un destino fatal: "El arco negro se tendió ante la aurora / y en el último astro fue a clavarse la flecha" (vv. 22-23). Por otro lado, el sol, ese símbolo tan importante en las concepciones cosmológicas mesoamericanas, ha sido fragmentado por la Colonia y el legado de la colonialidad y apenas sobrevive en manos del poeta:
Y es así como en este día con el sol roto entre mis manos oigo rodar en mi destino, como en un bosque de cactus, la maldición de los dioses...

(vv. 47-51)

Además de estar roto y "hundido entre el fango y el miedo" (v. 100), ese sol luminoso ha sido reemplazado por la estrella "tristísima" de Quetzalcóatl que sugiere un destino fatal, "la maldición de los dioses" (v. 51), por la asociación mítica del dios prehispánico con la llegada de los europeos. El poeta desea vencer y destruir esa estrella "tristísima" de Quetzalcóatl, iluminando la lucha de Cuauhtémoc como modelo para el presente. Sin embargo, su deseo queda frustrado por la amenaza de una nueva invasión cultural. Así, el "flechazo" que había lanzado Cuauhtémoc hacia el lucero de Quetzalcóatl, simbólicamente buscando vencer la colonialidad, queda frustrado:

¿Quién puede mirar con ojo de dulzura

la dulzura misteriosa del cielo si la ignominia y la infamia buscan sepultarnos otra vez bajo su estrépito de acero? Los hombres del Norte piratean a su antojo al Continente y las Islas y se agregan pedazos de cielo. [...]

Llenas el muro colosal de mi angustia y frustras el flechazo que iba hacia algún lucero. (vv. 87-92, 94-95; cursivas mías) 
Escribiendo en 1924, el poeta reflexiona sobre el poder creciente de los Estados Unidos y se pregunta si la historia de la Conquista se repetirá con invasores nuevos:

¿Volverás a ponernos las plantas en el fuego?

¿Vendrás con tus manos brutales

del país de los yanquis, mediocre, ordenado y corpulento?

¿Y entre estallidos y máquinas

a robar, a matar, a comprar caciques con tu inacabable dinero?

(vv. 105-109)

El final del poema convoca de nuevo el espíritu de resistencia de Cuauhtémoc como la esperanza de América Latina. Aunque el sol fue vencido en la leyenda de Tilantongo, Pellicer lamenta que la flecha de Cuauhtémoc todavía no ha podido vencer este astro maligno, símbolo de la colonialidad y de un destino fatal. Sin embargo, el poeta afirma que el espíritu de Cuauhtémoc sobrevive en su corazón y podrá salvar al pueblo en el futuro:

¡Tu vida es la flecha más alta que ha herido

los ojos del Sol y ha seguido volando en el cielo!

Pero en el cráter de mi corazón

hierve la fe que salvará a tus pueblos.

(vv. 113-16)

Con este análisis de su transformación y actualización de los mitos de Quetzalcóatl y Tilantongo para elevar a Cuauhtémoc del orden histórico al orden simbólico mitológico, se vislumbra cómo Pellicer emplea un nuevo acercamiento profundo y comprometido a la historia y a la realidad propias. En su análisis del texto, Francisco Pabón subraya que "en el orden estético, Cuauhtémoc ha sido transfigurado en un sentimiento de signo político y personal e identificable con la realidad contemporánea de Pellicer" (76). La "Oda a Cuauhtémoc", además de celebrar la vida del mártir, también es un llamado a la unidad continental. De hecho, lo que más lamenta el poeta de la historia del guerrero es la falta de unidad en la resistencia: 
En mí ha quedado el instante
en que fue más terrible tu tristeza:
cuando buscaste alianzas
entre los hombres de tu raza
y tu grito se perdió entre las selvas.

(vv. 4-8)

Así se puede entender el poemario entero: una celebración de América Latina y un llamado a la unidad solidaria. ${ }^{7}$ Los textos de Piedra de sacrificios: Poema iberoamericano celebran toda América Latina, cantando su geografía, sus pueblos, su historia y sus héroes y llamando a la unión continental. Esperemos con esa fe volcánica del corazón del poeta que la historia no se repita y que Cuauhtémoc siga siendo un modelo para la lucha solidaria contra las cadenas de la dependencia, el eurocentrismo y la colonialidad.

La intención del presente estudio ha sido elucidar la cualidad precursora de la poesía temprana de Pellicer de la nueva conciencia histórica que surge en la lírica continental, llegando a su apogeo en la poesía de los 1950 y 1960. Aunque los dos poemas juveniles de 1914 y 1916 se aferran a la estética del preciosismo modernista y demuestran un acercamiento todavía exotista, evocan la historia prehispánica y la lírica náhuatl, tradiciones propias y oriundas, en lugar de evocar una historia y una tradición poética ajenas. Pellicer rechaza ese mundo cosmopolita tan característico del Modernismo; como algunos otros poetas contemporáneos, vuelve su mirada sobre el pasado precolombino de América Latina. Además, aquel exotismo en el tratamiento de la historia, característico del modernismo cosmopolita, es reemplazado por un tratamiento más profundo y comprometido en Piedra de sacrificios, su poemario de 1924. En un ensayo escrito por el poeta en 1923 para la revista Azulejos sobre la obra de Diego Rivera, queda claro su

${ }^{7}$ Así, el espíritu de la oda de Pellicer, publicada en 1924, coincide con el espíritu de la réplica del monumento a Cuauhtémoc en el Paseo de la Reforma que se hizo ese mismo ańo y que el gobierno mexicano le regaló a Brasil para celebrar el centenario de su independencia. Según Fulton, "the figure of Cuauhtémoc was chosen because it symbolized the fraternity of Latin American countries and the common origin of the region's people [... and] to assert mexico's leadership in the union of Latin States that was then being formed" (2008b: 8-9). 
pensamiento sobre la Conquista y la imposición cultural que derribó estas expresiones en el espacio simbólico prehispánico:

México ha empezado su mexicanización. La Patria no se hace copiando sino creando y aquilatando las verdaderas tradiciones del arte mexicano, que ha sido siempre un gran arte. Lo que nos trajeron los Destructores encabezados por el bestial Hernán Cortés distaba mucho de ser superior a lo que aquí había. Perdimos casi completamente nuestra profunda y espléndida originalidad para recibir a golpes la mediocridad grecoromana del Renacimiento tamizada a través de Espańa. Después de la Revolución, la Nación ha empezado a consagrarse a sí misma... (citado en Pabón: 51).

Pellicer reivindica y reincorpora a la lírica mexicana mitos, símbolos y motivos del arte precolombino, tanto plástico como literario, demostrando también una creciente conciencia histórica del pasado ancestral. La insistencia en la raíz oriunda en su obra revela una reflexión profunda sobre lo que difiere la identidad hispanoamericana de la europea. Su mundo poético se independiza de la tradición europea y emprende una búsqueda profunda de la identidad propia. Por eso, podemos reafirmar a Carlos Pellicer como un poeta clave no solo en la trayectoria de la lírica mexicana, sino también en la continental.

\section{Bibliografía}

Casal, Julián del. "La agonía de Petronio". Antología crítica de la poesía modernista hispanoamericana. Ed. José Olivio Jiménez. 4a . ed. Madrid: Hiperión, 1994. 121-122.

Dávila Garibi, José Ignacio. Episodios de la vida de Netzahualcóyotl [1911]. 3a. ed. México: Secretaría de Educación Pública, 1947.

Fulton, Christopher. "Cuauhtémoc Awakened”. Estudios de Historia Moderna y Contemporánea de México 35 (enero-junio 2008a): 5-47.

Fulton, Christopher. "Cuauhtémoc Regained”. Estudios de Historia Moderna y Contemporánea de México 36 (julio-diciembre 2008b): 5-43.

Garibay K., Ángel María. Poesía náhuatl. 3 vols. México: Universidad Nacional Autónoma de México, 1965.

Garibay K., Ángel María. Historia de la literatura náhuatl. México: Porrúa, 1992. 
Gay, José Antonio. Historia de Oaxaca [1881]. México: Porrúa, 1982.

LeIva, Raúl. Imagen de la poesía mexicana contemporánea. México: Universidad Nacional Autónoma de México, 1959.

Moretta, Eugene. "Carlos Pellicer y la poesía de compromiso social”. Essays in Honor of Frank Dauster. Eds. Kirsten F. Nigro \& Sandra M. Cypess. Newark, NE: Juan de la Cuesta, 1995. 87-103.

Mullen, Edward J. "Motivos precolombinos en la poesía de Carlos Pellicer". Explicación de Textos Literarios 3 (1974): 51-57.

Pabón, Francisco. "Gravitación de lo indígena en la poesía de Carlos Pellicer”. Diss. Rutgers U, 1969.

Paz, Octavio. "Prefacio. Poesía en movimiento". Poesía en movimiento. México, 1915-1966. 1ª. ed. México: Siglo XXI, 1966. 3-34.

Paz, Octavio. Las peras del olmo. Barcelona: Seix Barral, 1971.

Paz, Octavio. "Literatura de fundación”. Puertas al campo. Barcelona: Seix Barral, 1972. 15-21.

Pellicer, Carlos. Poesía completa. 3 vols. Eds. Luis Mario Schneider y Carlos Pellicer López. México: El Equilibrista, 1996.

Pellicer, Carlos. "Tríptico azteca”. Poesía completa 3: 39-41.

Pellicer, Carlos. "Oda a Cuauhtémoc”. Poesía completa 1: 109-112.

Pellicer, Carlos. "La elegía de tus ojos". Poesía completa 3: 32-34.

Pellicer, Carlos. "La muerte de Petronio". Poesía completa 3: 111-114.

Pellicer, Carlos. "Imperial agonía”. Poesía completa 3: 203-204.

Rivera-Rodas, Óscar. "Modernidad y postmodernidad literarias en Hispanoamérica”. Conjuntos: Teorías y enfoques literarios recientes. Comp. Alberto Vital. México: Universidad Nacional Autónoma de México, 1996. 447-469.

Rivera-Rodas, Óscar. Picón Salas: Historia de la cultura y cosmopolitismo. Caracas, Venezuela: Centro de Estudios Latinoamericanos Rómulo Gallegos, 2011.

Selva, Mauricio de la. "Homenaje a Carlos Pellicer: Poeta de América". Cuadernos Americanos 212 (1977): 59-106.

Westheim, Paul. The Art of Ancient Mexico. Trad. Ursula Bernard. Garden City, NY: Doubleday, 1965.

Fecha de Recepción: 22 de julio de 2013

FECHA DE ACEPTACión: 07 de octubre de 2013 